\title{
Intravenous administration of anakinra in children with macrophage activation syndrome
}

\author{
Omkar Phadke ${ }^{1,2^{*}} \mathbb{D}$, Kelly Rouster-Stevens ${ }^{1,2}$, Helen Giannopoulos ${ }^{2}$, Shanmuganathan Chandrakasan ${ }^{1,2}$ and \\ Sampath Prahalad ${ }^{1,2}$
}

\begin{abstract}
Background: Subcutaneous anakinra is an interleukin-1 inhibitor used to treat juvenile idiopathic arthritis. Recent reports suggest anakinra can be a valuable addition to the treatment of COVID-19 associated cytokine storm syndrome and the related multisystem inflammatory syndrome (MIS-C) in children. Herein, we describe our experience with intravenously administered anakinra.

Findings: 19 Patients (9 male) received intravenous (IV) anakinra for treatment of macrophage activation syndrome (MAS) secondary to systemic lupus erythematosus (SLE), systemic JIA (SJIA) or secondary hemophagocytic lymphohistiocytosis (sHLH). In most cases the general trend of the fibrinogen, ferritin, AST, and platelet count (Ravelli criteria) improved after initiation of IV anakinra. There were no reports of anaphylaxis or reactions associated with administration of IV anakinra.

Conclusion: Intravenous administration of anakinra is an important therapeutic option for critically ill patients with MAS/HLH. It is also beneficial for those with thrombocytopenia, subcutaneous edema, neurological dysfunction, or very young, hospitalized patients who need multiple painful subcutaneous injections.
\end{abstract}

\section{Background}

Anakinra is a $17 \mathrm{KD}$ recombinant, non-glycosylated Interleukin-1 (IL-1) receptor antagonist. Subcutaneous (SC) anakinra is used in the treatment of systemic JIA (SJIA) [1, 2]. Anakinra has also been described to be effective in the treatment of macrophage activation syndrome (MAS) secondary to sJIA as well as other rheumatic diseases like systemic lupus erythematosus (SLE) and Kawasaki Disease (KD) [2-5]. Recent reports show anakinra can be effective in secondary hemophagocytic lymphohistiocytosis (sHLH) due to non-rheumatic diseases as well [6]. In some situations, such as thrombocytopenia, subcutaneous edema or in children

\footnotetext{
* Correspondence: ophadke@emory.edu

'Department of Pediatrics, Emory University School of Medicine, Atlanta, GA, USA

${ }^{2}$ Children's Healthcare of Atlanta, Atlanta, GA, USA
}

in intensive care setting, it may be necessary to use intravenous (IV) administration of anakinra instead of SC anakinra. There have only been a few studies that evaluated the pharmacokinetics of IV anakinra in the past [7]. In the present era of COVID-19, high-dose anakinra has been shown to improve outcomes associated with hyper-inflammation observed both with SARS$\mathrm{CoV}-2$ infections and the newly described multisystem inflammatory syndrome in children (MIS-C) [8-10]. We sought to describe our experience with IV anakinra in children with MAS at our institution prior to COVID-19 in order to guide clinicians wishing to consider this therapy for indications such as hyperinflammation seen with COVID-19 and MIS-C.

C C The Author(s). 2021 Open Access This article is licensed under a Creative Commons Attribution 4.0 International License, which permits use, sharing, adaptation, distribution and reproduction in any medium or format, as long as you give appropriate credit to the original author(s) and the source, provide a link to the Creative Commons licence, and indicate if changes were made. The images or other third party material in this article are included in the article's Creative Commons licence, unless indicated otherwise in a credit line to the material. If material is not included in the article's Creative Commons licence and your intended use is not permitted by statutory regulation or exceeds the permitted use, you will need to obtain permission directly from the copyright holder. To view a copy of this licence, visit http://creativecommons.org/licenses/by/4.0/ The Creative Commons Public Domain Dedication waiver (http://creativecommons.org/publicdomain/zero/1.0/) applies to the data made available in this article, unless otherwise stated in a credit line to the data. 


\section{Methods}

In collaboration with our hospital pharmacists, a protocol was designed for the use of IV anakinra in our center. The protocol outlines potential use of IV anakinra in patients with an underlying rheumatic condition (such as SJIA, SLE, KD) with features of MAS or secondary $\mathrm{HLH}$. These patients may require high doses of anakinra, require multiple subcutaneous injections, may have subcutaneous edema, thrombocytopenia, or coagulopathy. For patients naïve to anakinra, the dose was started at 2 $\mathrm{mg} / \mathrm{kg}$ and titrated up to a maximum of $100 \mathrm{mg}$ IV every $12 \mathrm{~h}$ according to the patient's clinical status. For patients already on maintenance anakinra and admitted to hospital, anakinra was titrated up to a maximum of 100 mg IV every $6 \mathrm{~h}$ according to the patient's clinical status. The SC formulation was mixed in normal saline with 1 $\mathrm{ml}$ of normal saline per $1 \mathrm{mg}$ of anakinra, administered IV over $30 \mathrm{~min}$.
An IRB-approved retrospective chart review of various clinical and demographic variables via electronic medical record were identified for patients that had received IV anakinra at our institution between January 2017 and December 2019.

The duration of therapy, doses and outcome of the patients were recorded. MAS laboratory values as described by the Ravelli criteria [11] were identified prior to and 24 to $48 \mathrm{~h}$ after conclusion of administration of IV anakinra.

\section{Findings}

In all, 19 patients ( 9 male) received IV anakinra (Table 1 ). All patients met the 2016 Ravelli criteria for MAS [11], except patient \#1 and \#5, in whom a clinical decision was made to start anakinra due to rising ferritin and transaminases. Eleven patients were in a critical care setting during administration. Median age of our cohort

Table 1 Clinical and laboratory characteristics of patients that received intravenous anakinra

\begin{tabular}{|c|c|c|c|c|c|c|c|c|c|c|c|c|c|c|c|}
\hline \multirow{2}{*}{$\begin{array}{l}\text { Patient } \\
1\end{array}$} & \multirow{2}{*}{$\begin{array}{l}\text { Age } \\
\\
1 \\
1\end{array}$} & \multirow{2}{*}{$\begin{array}{l}\text { Sex } \\
\\
M\end{array}$} & \multirow{2}{*}{$\begin{array}{l}\text { Diagnosis } \\
\\
\text { SJIA }\end{array}$} & \multicolumn{2}{|c|}{$\begin{array}{l}\text { Anakinra } \\
\text { dose } \\
\text { (mg/kg/ } \\
\text { d) Initial } \\
\text { Max }\end{array}$} & \multirow{2}{*}{$\begin{array}{l}\begin{array}{l}\text { Duration } \\
\text { (Days) }\end{array} \\
3\end{array}$} & \multirow{2}{*}{$\begin{array}{l}\text { Triglycerides }(\mathrm{mg} / \mathrm{dl}) \\
\text { baseline } \\
109\end{array}$} & \multicolumn{2}{|c|}{$\begin{array}{l}\text { Ferritin (ng/dl) } \\
\text { Pre-Post }\end{array}$} & \multicolumn{2}{|c|}{$\begin{array}{l}\text { AST (U/L) } \\
\text { Pre-Post }\end{array}$} & \multicolumn{2}{|c|}{$\begin{array}{l}\text { Fibrinogen } \\
\text { (mg/dl) } \\
\text { Pre-Post }\end{array}$} & \multicolumn{2}{|c|}{$\begin{array}{l}\text { Platelets } \\
\text { (1000/ } \\
\text { UL) Pre } \\
\text { post }\end{array}$} \\
\hline & & & & 4 & 7.2 & & & 4667 & 2132 & 53 & 52 & 504 & 253 & 568 & 505 \\
\hline 2 & 3 & $\mathrm{~F}$ & SJIA & 7.4 & 7.4 & 11 & 160 & $\begin{array}{l}130 \\
000\end{array}$ & 3486 & 164 & 45 & 168 & 202 & 46 & 70 \\
\hline 3 & 4 & M & SJIA & 7.8 & 15.4 & 5 & 102 & 8663 & 1097 & 766 & 160 & 81 & 170 & 84 & 173 \\
\hline 4 & 6 & M & SJIA & 20 & 20 & 12 & Not done & 10,437 & 137 & 168 & 24 & 196 & 126 & 211 & 265 \\
\hline 5 & 8 & $\mathrm{~F}$ & SJIA & 8 & 8 & 3 & 83 & 5160 & 1954 & 74 & 472 & 426 & 392 & 343 & 591 \\
\hline 6 & 13 & $\mathrm{~F}$ & SJIA & 3.3 & 7.5 & 10 & 197 & 21,442 & 1442 & 935 & 42 & 83 & 152 & 113 & 267 \\
\hline 7 & 13 & $\mathrm{~F}$ & SJIA & 11 & 11 & 8 & 249 & 55,000 & 3933 & 325 & 107 & 118 & 91 & 120 & 311 \\
\hline 8 & 16 & M & SJIA & 9.4 & 9.4 & 5 & 207 & 2016 & 294 & 16 & 13 & 637 & 509 & 471 & 429 \\
\hline 9 & 16 & M & SJIA & 6 & 6 & 2 & 176 & 17,033 & 3850 & 125 & 120 & 221 & 221 & 180 & 243 \\
\hline $10^{* *}$ & 20 & $\mathrm{~F}$ & SJIA & 1.7 & 6.8 & 5 & 152 & 84,000 & 10 & 1812 & 314 & 170 & 319 & 23 & 81 \\
\hline 11 & 16 & $\mathrm{~F}$ & Lupus & 2.5 & 8 & 47 & 268 & 12,098 & 412 & 432 & 6 & 323 & 214 & 139 & 150 \\
\hline 12 & 16 & M & Lupus & 6.6 & 6.6 & 10 & 165 & 5195 & 557 & 361 & 40 & 362 & 607 & 134 & 287 \\
\hline 13 & 20 & M & Lupus & 10 & 10 & 85 & 782 & $\begin{array}{l}120 \\
000\end{array}$ & 1421 & 2521 & 23 & 190 & 158 & 239 & 188 \\
\hline $14^{* *}$ & 13 & M & Vasculitis & 7.1 & 14.2 & 54 & 203 & 3186 & $\begin{array}{l}12 \\
398\end{array}$ & 46 & 128 & 321 & 779 & 22 & 42 \\
\hline 15 & 3 & $\mathrm{~F}$ & sHLH & 4 & 20 & 16 & 333 & $\begin{array}{l}110 \\
000\end{array}$ & 1240 & 66 & 28 & 335 & 155 & 298 & 290 \\
\hline 16 & 9 & M & sHLH & 3 & 11 & 13 & 209 & 15,750 & 7855 & 41 & 42 & 295 & 405 & 709 & 174 \\
\hline $17^{* *}$ & 10 & $\mathrm{~F}$ & SHLH & 4 & 8 & 2 & 2617 & 1216 & $\begin{array}{l}15 \\
577\end{array}$ & 270 & 394 & 674 & 489 & 19 & 99 \\
\hline $18^{* *}$ & 12 & $F$ & sHLH & 2.2 & 4.2 & 9 & 336 & 92,000 & $\begin{array}{l}67 \\
000\end{array}$ & 265 & 26 & 375 & 595 & 12 & 101 \\
\hline $19^{* *}$ & 19 & $\mathrm{~F}$ & sHLH & 8 & 8 & 20 & 272 & 13,756 & 8004 & 166 & 134 & 376 & 205 & 60 & 56 \\
\hline
\end{tabular}

Ravelli criteria include Ferritin $>684 \mathrm{ng} / \mathrm{dl}$ plus any $2 / 3$ of TG $>156 \mathrm{mg} / \mathrm{dl}, \mathrm{PLT}<181$ (1000/UL), AST $>48 \mathrm{U} / \mathrm{L}$, Fibrinogen $<360 \mathrm{mg} / \mathrm{dl}$. Values meeting these criteria shown in italics and bold. All patients except patient \#1 and \#5 met Ravelli criteria 2016, who had elevation in ferritin and elevated AST only Patient with ** (Patient \#10,\#14,\#17, 18\# and \#19) are deceased 
was 13 years. Indication was MAS secondary to SJIA $(n=10)$, SLE $(n=3)$, sHLH $(n=5)$ and other $(n=1)$. All 5 patients with sHLH met 2004 HLH criteria [12] (Table 2). Maximum duration of therapy was 85 days. Median duration of therapy was 10 days. The initial dose of IV anakinra ranged from 1.7 to $10 \mathrm{mg} / \mathrm{kg} /$ day and the maximum dose of IV anakinra ranged from 4.2-15.4 $\mathrm{mg} / \mathrm{kg} /$ day. One patient (\#4) was already on $100 \mathrm{mg}$ SQ Q12 of anakinra at home, and this was increased to 100 mg Q6 IV $(20 \mathrm{mg} / \mathrm{kg} /$ day) to successfully treat an acute episode of MAS. The maximum frequency of administration was every $6 \mathrm{~h}$. In most cases the general trend of the fibrinogen, ferritin, AST, and platelet count improved after initiation of IV anakinra. There were no reports of anaphylaxis or reactions associated with administration of IV anakinra.

Increased transaminases were noticed in patient \#5 who received a maximum dose of $8 \mathrm{mg} / \mathrm{kg} /$ day $(224 \mathrm{mg})$; discontinuation of anakinra resulted in normalization of AST and ALT. Five (26.3\%) of the patients died from their underlying disease or complications. Other medications received by patients who died are depicted in Table 3. Patient \#10 had SJIA and MAS; MAS laboratory parameters improved after IV anakinra administration. However, she developed Methicillin sensitive Staphylococcus aureus bacteremia (MSSA) leading to multi organ failure and cardiorespiratory arrest. Patient \#14 had recurrent refractory ischemic strokes secondary to vasculitis of unknown etiology and multi-organ failure with MAS. Patient \#17 with primary immune dysregulation (mutation in MUNC 13) died of overwhelming cytomegalovirus viremia (CMV) and MSSA bacteremia. Patient \#18 with refractory HLH and CNS involvement also had overwhelming sepsis. Patient \#19 with HLH status post BMT and recurrent CMV viremia died from multi organ failure, however anakinra had been used a year prior to her death. Three of these patients (\#10, \#18, \#19) had improvement in the Ravelli MAS laboratory parameters in response to IV anakinra despite their fatal outcome.

\section{Discussion}

Our experience with IV anakinra administration prior to the recent COVID-19 pandemic indicates that intravenously administered anakinra was overall safe and well tolerated with minimal adverse effects apart from one case of elevated transaminases, which is a known side effect of SC anakinra and described by Canna et al. [13]. There were no reported instances of anaphylaxis. It was effective for the treatment of MAS with improvement of laboratory parameters in most instances. Thus, IV anakinra may be an important therapeutic option for critically ill patients, although there is limited literary evidence regarding the pharmacokinetics, absorption, and efficacy of IV anakinra.

Prior studies of IV anakinra in sepsis have not shown an increase risk of adverse effects. In 1994, Fisher et al. [14] reported no statistically significant increase in survival time for Interleukin-1 antagonist treatment compared with placebo among all patients who received the study medication or among patients with sepsis. In a multicenter trial in 1997, Opal et al. [15] failed to demonstrate a statistically significant reduction in mortality when continuous IL-1 receptor antagonist infusions were compared with standard therapy in sepsis. In both these instances no excess adverse effects or microbial superinfections were attributed to the IL-1 inhibitor [14, 15]. In a large cohort of 763 patients, Shakoory et all in 2016 showed significant clinical improvement with

Table 2 Features of patients meeting HLH 2004 criteria

\begin{tabular}{|c|c|c|c|c|c|}
\hline & $\begin{array}{l}\text { Patient } \\
15\end{array}$ & $\begin{array}{l}\text { Patient } \\
16\end{array}$ & Patient 17 & $\begin{array}{l}\text { Patient } \\
18\end{array}$ & Patient 19 \\
\hline Familial Genetic Panel & Negative & Negative & $\begin{array}{l}\text { Heterozygous mutation: } \\
\text { UNC13D C753 + } 1 \mathrm{G}>\mathrm{T}\end{array}$ & Negative & $\begin{array}{l}\text { Heterozygous mutations: STXBP2 } \\
\text { T248M LYST R3412H }\end{array}$ \\
\hline Fever $>7$ days & Yes & Yes & Yes & Yes & Yes \\
\hline Splenomegaly & No & No & No & Yes & No \\
\hline Cytopenia's (> 2 lineages) $)^{x}$ & No & No & Yes & Yes & Yes \\
\hline $\begin{array}{l}\text { Hypertriglyceridemia (> } 265 \mathrm{mg} / \mathrm{dl} \text { ) or } \\
\text { Hypofibrinogenemia (< } 150 \mathrm{mg} / \mathrm{dL} \text { ) }\end{array}$ & Yes & Yes & Yes & Yes & Yes \\
\hline Hemophagocytes on bone marrow & Yes & Yes & Not done & Yes & No \\
\hline Low NK cell activity & No & Yes & Yes & Yes & No \\
\hline Ferritin > 500 micrograms/ L & Yes & Yes & Yes & Yes & Yes \\
\hline Soluble CD25 > $2400 \mathrm{U} / \mathrm{mL}$ & Yes & Yes & No & No & Yes \\
\hline
\end{tabular}

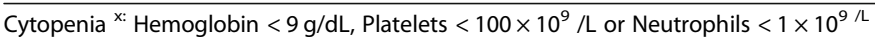

Patients meeting HLH 2004 criteria. To fulfil HLH 2004 criteria patients had to meet at least 5 of 8 criteria. All five patients met criteria

Patient \#17 and \#19 had heterozygous mutations in UNC13D, STXBP2 and LYST genes. These genes have been shown to harbor pathogenic variants related to Hemophagocytic Lymphohistiocytosis 
Table 3 Other medications received by selected patients

\begin{tabular}{llll}
\hline Patient number & Diagnosis & Other immunosuppressive medications used during admission & Outcome \\
\hline 10 & SJIA & Methylprednisolone, Etoposide, Dexamethasone, Jakafi & Deceased \\
14 & Unclassified Vasculitis & Cyclophosphamide, Rituximab, Eculizumab & Deceased \\
17 & SHLH & Ruxolitinib, Methylprednisolone & Deceased \\
18 & SHLH & Dexamethasone, Cyclosporin, Etoposide & Deceased \\
19 & SHLH & Mycophenolate, Steroids, Eculizumab & Deceased \\
15 & SHLH & Dexamethasone, Etoposide & Recovered \\
16 & SHLH & Dexamethasone, Etoposide & Recovered \\
\hline
\end{tabular}

Other medications received in selected patients (deceased and/or those with sHLH) during the admission at which IV anakinra was used

treatment of IV anakinra vs placebo for sepsis patients with features of MAS [16].

Mehta et al. recently described high dose IV anakinra for MAS/HLH in cytokine storm syndromes [10]. They used IV anakinra in 39\% of their patient population with cytokine storm and no adverse effects were seen. Cavalli et al. used IV anakinra at $10 \mathrm{mg} / \mathrm{kg} /$ day and showed improvement in COVID-19 associated hyperinflammation in $72 \%$ of their cohort [8]. Montegudo et al. used continuous Anakinra (2400 mg/day) in treatment of MAS/ sHLH with clinical improvement in $4 / 5$ patients [17]. In a recent paper (December 2020) Kavirayani et al. successfully used IV anakinra at extremely high doses (48 $\mathrm{mg} / \mathrm{kg} /$ day) for the treatment of non- familial CNS HLH even in the setting of intercurrent infections [18]. Thus, IV anakinra could be an option for treating COVID-19 associated hyperinflammatory state and/or cytokine storm in selected patients and appears to be well tolerated at high doses and in the setting of sepsis.

Limitations of our study include that it was retrospective in nature and only a relatively modest number of patients were included. However, we believe these cases are illustrative regarding the use of IV anakinra. Fatal outcome was observed in five patients in our series (26.3\%) similar to findings noted by Eloseily et al. [19]. These patients either had severe, refractory disease or were immunosuppressed prior to IV anakinra exposure due to other medications/ post bone marrow transplant. Despite this, the laboratory indicators of MAS improved in three of the patients who succumbed to their illness.

\section{Conclusion}

In summary, intravenous administration of anakinra is an important therapeutic option for critically ill patients with MAS/HLH. It is also beneficial for those with thrombocytopenia, subcutaneous edema, neurological dysfunction, or very young, hospitalized patients who need multiple painful injections.

\section{Abbreviations}

MISC: Multisystem inflammatory syndrome (MISC); SJIA: Systemic JIA; MAS: Macrophage Activation Syndrome; SHLH: Secondary Hemophagocytic lymphohistiocytosis; SC: Subcutaneous; KD: Kawasaki disease;
CMV: Cytomegalovirus; MSSA: Methicillin sensitive Staphylococcus aureus bacteremia; IL-1: Interleukin-1; PLT: Platelets; SLE: Systemic lupus erythematosus

\section{Acknowledgements}

NA

Authors' contributions

OP and SP contributed to study design, data collection, data analysis; drafted and revised the manuscript critically for intellectual content and gave the final approval for the published version. HG contributed to data collection, revised the manuscript critically for intellectual content and gave the final approval for the published version. SC and KRS contributed to the study design and data analysis, revised the manuscript critically for intellectual content and gave the final approval for the published version.

\section{Funding}

Dr. Prahalad is supported in part, by the Marcus Foundation Inc., Atlanta. No additional funding was secured for this study.

\section{Availability of data and materials}

All data generated or analyzed during this study are included in this published article.

\section{Declarations}

Ethics approval and consent to participate

The present study was approved by the Institutional Review Board (IRB) at CHOA via waiver of informed consent (STUDY00000349).

Consent for publication

Not applicable.

\section{Competing interests}

Dr. Prahalad serves on a Macrophage Activation Syndrome Adjudication Committee for Novartis Pharmaceuticals. Dr Kelly Rouster-Stevens serves on the Accordant Medical Board. The remaining authors have no conflicts of interest to declare.

Received: 26 February 2021 Accepted: 5 April 2021

Published online: 29 June 2021

References

1. Nigrovic PA, Mannion M, Prince FH, Zeft A, Rabinovich CE, van Rossum MA, et al. Anakinra as first-line disease-modifying therapy in systemic juvenile idiopathic arthritis: report of forty-six patients from an international multicenter series. Arthritis Rheum. 2011;63(2):545-55. https://doi.org/10.1 002/art.30128

2. Zeft A, Hollister R, LaFleur B, Sampath P, Soep J, McNally B, et al. Anakinra for systemic juvenile arthritis: the Rocky Mountain experience. J Clin Rheumatol. 2009;15(4):161-4. https://doi.org/10.1097/RHU.0b013e3181a4f459.

3. Aytac S, Batu ED, Unal S, Bilginer Y, Cetin M, Tuncer M, et al. Macrophage activation syndrome in children with systemic juvenile idiopathic arthritis and systemic lupus erythematosus. Rheumatol Int. 2016:36(10):1421-9. https://doi.org/10.1007/s00296-016-3545-9. 
4. Record JL, Beukelman T, Cron RQ. Combination therapy of abatacept and anakinra in children with refractory systemic juvenile idiopathic arthritis: a retrospective case series. J Rheumatol. 2011;38(1):180-1. https://doi.org/10.3 899/irheum.100726.

5. Shafferman A, Birmingham JD, Cron RQ. High dose Anakinra for treatment of severe neonatal Kawasaki disease: a case report. Pediatr Rheumatol Online J. 2014;12(1):26. https://doi.org/10.1186/1546-0096-12-26.

6. Bami S, Vagrecha A, Soberman D, Badawi M, Cannone D, Lipton JM, et al. The use of anakinra in the treatment of secondary hemophagocytic lymphohistiocytosis. Pediatr Blood Cancer. 2020:e28581. https://doi.org/10.1 002/pbc.28581.

7. Galea J, Ogungbenro K, Hulme S, Greenhalgh A, Aarons L, Scarth S, et al. Intravenous anakinra can achieve experimentally effective concentrations in the central nervous system within a therapeutic time window: results of a dose-ranging study. J Cereb Blood Flow Metab. 2011;31(2):439-47. https:// doi.org/10.1038/jcbfm.2010.103.

8. Cavalli G, De Luca G, Campochiaro C, Della-Torre E, Ripa M, Canetti D, et al. Interleukin-1 blockade with high-dose anakinra in patients with COVID-19, acute respiratory distress syndrome, and hyperinflammation: a retrospective cohort study. Lancet Rheumatol. 2020;2(6):e325-e31. https://doi.org/10.101 6/52665-9913(20)30127-2.

9. Mehta P, Cron RQ, Hartwell J, Manson JJ, Tattersall R. Intravenous anakinra for cytokine storm syndromes - Authors' reply. Lancet Rheumatol. 2020;2(9): e522-e3. https://doi.org/10.1016/S2665-9913(20)30215-0.

10. Mehta P, Cron RQ, Hartwell J, Manson JJ, Tattersall RS. Silencing the cytokine storm: the use of intravenous anakinra in haemophagocytic lymphohistiocytosis or macrophage activation syndrome. Lancet Rheumatol. 2020;2(6):e358-e67. https://doi.org/10.1016/S2665-9913(20)30096-5.

11. Ravelli A, Minoia F, Davi S, Horne A, Bovis F, Pistorio A, et al. 2016 classification criteria for macrophage activation syndrome complicating systemic juvenile idiopathic arthritis: a European league against rheumatism/American College of Rheumatology/Paediatric rheumatology international trials organisation collaborative initiative. Ann Rheum Dis. 2016;75(3):481-9. https://doi.org/10.1136/annrheumdis-2015-208982.

12. Zhang JR, Liang XL, Jin R, Lu G. HLH-2004 protocol: diagnostic and therapeutic guidelines for childhood hemophagocytic lymphohistiocytosis. Zhongguo Dang Dai Er Ke Za Zhi. 2013;15(8):686-8.

13. Canna S, Frankovich J, Higgins G, Narkewicz MR, Nash SR, Hollister JR, et al. Acute hepatitis in three patients with systemic juvenile idiopathic arthritis taking interleukin-1 receptor antagonist. Pediatr Rheumatol Online J. 2009; 7(1):21. https://doi.org/10.1186/1546-0096-7-21.

14. Fisher CJ Jr, Dhainaut JF, Opal SM, Pribble JP, Balk RA, Slotman GJ, et al. Recombinant human interleukin 1 receptor antagonist in the treatment of patients with sepsis syndrome. Results from a randomized, double-blind, placebo-controlled trial. Phase III rhll-1ra Sepsis syndrome study group. JAMA. 1994;271(23):1836-43. https:/doi.org/10.1001/jama.1994.03510470040032.

15. Opal SM, Fisher CJ Jr, Dhainaut JF, Vincent JL, Brase R, Lowry SF, et al. Confirmatory interleukin-1 receptor antagonist trial in severe sepsis: a phase III, randomized, double-blind, placebo-controlled, multicenter trial. The Interleukin-1 receptor antagonist Sepsis Investigator Group. Crit Care Med. 1997;25(7):1115-24. https://doi.org/10.1097/00003246-199707000-00010.

16. Shakoory B, Carcillo JA, Chatham WW, Amdur RL, Zhao H, Dinarello CA, et al. Interleukin-1 receptor blockade is associated with reduced mortality in Sepsis patients with features of macrophage activation syndrome: reanalysis of a prior phase III trial. Crit Care Med. 2016;44(2):275-81. https://doi.org/1 0.1097/CCM.0000000000001402.

17. Monteagudo LA, Boothby A, Gertner E. Continuous intravenous Anakinra infusion to calm the cytokine storm in macrophage activation syndrome. ACR Open Rheumatol. 2020;2(5):276-82. https://doi.org/10.1002/acr2.11135.

18. Kavirayani A, Charlesworth JEG, Segal S, Kelly D, Wilson S, Qureshi A, et al. The Lazarus effect of very high-dose intravenous anakinra in severe nonfamilial CNS-HLH. Lancet Rheumatol. 2020;2(12):e736-e8. https://doi.org/10.1 016/S2665-9913(20)30361-1.

19. Eloseily EM, Weiser P, Crayne CB, Haines H, Mannion ML, Stoll ML, et al. Benefit of Anakinra in treating pediatric secondary Hemophagocytic Lymphohistiocytosis. Arthritis Rheum. 2020;72(2):326-34. https://doi.org/10.1 002/art.41103

\section{Publisher's Note}

Springer Nature remains neutral with regard to jurisdictional claims in published maps and institutional affiliations.

\section{Ready to submit your research? Choose BMC and benefit from}

- fast, convenient online submission

- thorough peer review by experienced researchers in your field

- rapid publication on acceptance

- support for research data, including large and complex data types

- gold Open Access which fosters wider collaboration and increased citations

- maximum visibility for your research: over $100 \mathrm{M}$ website views per year

At BMC, research is always in progress.

Learn more biomedcentral.com/submissions 